JH lus Quia lustum is licensed under a Creative Commons Attribution 4.0 Internationa License. Which Permits unrestricted use, distrubution, and reproduction in any medium, prowided the original work is properly cited

\title{
Tinjauan Kasus Tentang Dilusi Merek Di Indonesia Dan Thailand
}

\author{
Rika Ratna Permata, Tasya Safiranita Ramli, dan Biondy Utama \\ Fakultas Hukum Universitas Padjadjaran Bandung \\ Jln. Raya Bandung Sumedang Km. 21 Jatinagor Bandung \\ permata_rika@yahoo.com; tasya_safiranita@yahoo.com; dan ubiondy@yahoo.com
}

Received: 6 Maret 2018; Accepted: 27 Maret 2019; Published: 24 April 2019

DOI: 10.20885/iustum.vol26.iss1.art1

\begin{abstract}
The use of well-known brands without any license, in practice, often intentionally or unintentionally occurs that not only leads violations but also confusion for the public. The use of a brand without any license - but not creating any public confusion - is referred to as brand dilution. This article aims to examine the brand dilution case occurred in Indonesia and Thailand by concerning with two issues: first, to study the case of IKEA vs. IKEMA occurred in Indonesia and the case of STARBUCKS vs. STARBUNG in Thailand including in the brand dilution. Second, to study the protection of well-known brands from brand dilution in Indonesia and Thailand. The research used was normative juridical method by means of the statute approach, case approach, analytical approach and comparative approach. The results of this study indicated that first the case of IKEA vs. IKEMA occurred in Indonesia and the case of STARBUCKS vs. STARBUNG is categorized as the brand dilution in consideration to the brand use that has a similarity to well-known brands. Though it has a different class of goods and/or services, it can eliminate the uniqueness of the famous brand. Second, both Indonesia and Thailand have not specifically regulated the brand dilution. Indonesia is only based on the overall protection on equality and/or equality in principle, while Thailand is only based protection on confusion.
\end{abstract}

Keywords: Brand; brand dilution; brand violation

\begin{abstract}
Abstrak
Penggunaan merek terkenal tanpa izin, dalam praktik sering terjadi, baik sengaja maupun tidak sengaja, yang menimbulkan pelanggaran juga kebingungan bagi masyarakat. Penggunaan merek tanpa izin namun tidak menimbulkan kebingungan masyarakat disebut sebagai dilusi merek. Artikel ini akan meneliti tentang kasus dilusi merek yang terjadi di Indonesia dan Thailand dengan mengangkat dua permasalahan, yaitu pertama mengkaji kasus IKEA v IKEMA yang terjadi di Indonesia dan kasus STARBUCKS v STARBUNG di Thailand termasuk ke dalam dilusi merek. Kedua, mengkaji perlindungan terhadap merek terkenal dari dilusi merek di Indonesia dan Thailand. Metode penelitian yang digunakan adalah yuridis normatif dengan pendekatan undang-undang (statute approach), pendekatan kasus (case approach), pendekatan analitis (analytical approach) dan pendekatan perbandingan (comparative approach). Hasil penelitian ini menyimpulkan pertama, Kasus IKEA v IKEMA yang terjadi di Indonesia dan Kasus STARBUCKS v STARBUNG termasuk ke dalam dilusi merek karena penggunaan merek yang mempunyai kemiripan dengan merek terkenal walaupun berbeda kelas barang dan atau jasa dapat menghilangkan keunikan merek terkenal tersebut. Kedua, baik Indonesia maupun Thailand belum mengatur secara spesifik mengenai dilusi merek. Indonesia hanya mendasarkan perlindungan pada persamaan pada keseluruhan dan/atau persamaan pada pokoknya sementara Thailand hanya mendasarkan perlindungan pada confusion (kebingungan).
\end{abstract}

Kata-kata Kunci: Merek; dilusi merek; pelanggaran merek 


\section{Pendahuluan}

Dewasa ini perdagangan di Indonesia cukup berkembang pesat. Perkembangan tersebut mengakibatkan tersedianya berbagai jenis barang dan/atau jasa bagi konsumen. Lazimnya, konsumen cenderung memilih barang dan/atau jasa yang kualitasnya sudah terjamin. Kualitas berkaitan dengan citra suatu produk di mata konsumen. Citra yang baik akan menjadikan produk tersebut menjadi pilihan konsumen di pasaran.

Konsumen dapat mengidentifikasi suatu produk yang satu dengan yang lainnya melalui sebuah merek. Merek adalah suatu tanda tertentu yang dipakai untuk mengidentifikasi suatu barang atau jasa sebagaimana barang atau jasa tersebut diproduksi atau disediakan oleh orang atau perusahaan tertentu. Merek membantu konsumen untuk mengidentifikasi dan membeli sebuah produk atau jasa berdasarkan karakter dan kualitasnya, yang dapat teridentifikasi dari mereknya yang unik.

Definisi merek menurut Pasal 1 angka 1 Undang-Undang Nomor 20 Tahun 2016 tentang Merek dan Indikasi Geografis (selanjutnya disebut UU Merek) adalah:

“Tanda yang dapat ditampilkan secara grafis berupa gambar, logo, nama, kata, huruf, angka, susunan warna, dalam bentuk 2 (dua) dimensi dan/atau 3 (tiga) dimensi, suara, hologram, atau kombinasi dari 2 (dua) atau lebih unsur tersebut untuk membedakan barang dan/atau jasa yang diproduksi oleh orang atau badan hukum dalam kegiatan perdagangan barang dan/atau jasa."

Sejarahnya, merek digunakan dalam pengertian yang sangat sempit, yaitu hanya digunakan sebagai "badge of origin"1 oleh penjual barang. Peran penting merek semakin dirasakan dari waktu ke waktu dalam setiap bidang kehidupan. Merek mengalami evolusi sehingga menjadi bagian dari budaya komersial yang pada awalnya belum mengenal perlindungan kekayaan intelektual. Dewasa ini, merek tidak hanya berfungsi untuk membedakan antara satu produk dengan produk lainnya melainkan memiliki peranan dalam representasi pihak penjual barang atau jasa. Dengan alasan itulah muncul pertimbangan bahwa merek patut untuk mendapatkan perlindungan hak kekayaan intelektual. ${ }^{2}$

${ }^{1}$ Menunjukkan hubungan antara barang atau jasa yang diperdagangkan dengan orang yang menjual dalam Frank I. Schecter, “The Rational Basis of Trademark Protection”, Harvard Law Review, Volume 40, No. 6, April 1927, hlm. 814

${ }^{2}$ Laina Rafianti dan M. Amirulloh, "Perlindungan merek Terkenal Di Indonesia Berdasarkan Ketentuan Hukum Internasional Dibandingkan Dengan Trademark Dilution Revision Act of 2006 Amerika Serikat", Laporan Penelitian Fakultas Hukum Universitas Padjadjaran, Bandung, 2008, hlm. 7. 
Merek sangat penting dalam dunia periklanan dan pemasaran karena publik sering mengaitkan suatu kesan (image), kualitas atau reputasi barang dan jasa dengan merek tertentu. Sebuah merek dapat menjadi kekayaan yang sangat berharga secara komersial. Merek suatu perusahaan seringkali lebih bernilai dibandingkan dengan aset riil perusahaan tersebut. ${ }^{3}$ Merek sebagai sarana pemasaran dan periklanan ( $a$ marketing and advertising device) memberikan suatu tingkat informasi tertentu kepada konsumen mengenai barang dan/atau jasa yang dihasilkan pengusaha. Lebih-lebih dengan perkembangan periklanan, baik nasional maupun internasional dewasa ini dan dalam rangka pendistribusian barang dan/atau jasa membuat merek semaking tinggi nilainya. ${ }^{4}$ Merek merupakan aset bisnis yang berharga dan merupakan bagian dari goodwill sebuah perusahaan. ${ }^{5}$

Pentingnya sebuah merek dalam pemasaran suatu produk barang dan/atau jasa melatarbelakangi perlunya suatu perlindungan terhadap merek. Merek dapat mempengaruhi konsumen untuk memutuskan membeli suatu produk karena mereka mengasosiasikan merek tersebut dengan kualitas yang sudah dikenal. ${ }^{6}$ Alasan-alasan di atas menyebabkan, banyak pihak yang melakukan tindakan pemalsuan merek, pendomplengan merek dan tindakan curang lainnya yang berkaitan dengan merek. Oleh karenanya diperlukan suatu pengaturan yang memberikan kepastian hukum dan perlindungan hukum bagi pemilik merek.

Salah satu perlindungan merek yang terdapat dalam UU Merek adalah perlindungan terhadap persamaan pada keseluruhan dan/atau persamaan pada pokoknya. Menurut teori hukum merek persamaan pada pokoknya adalah merek yang memiliki persamaan pada pokoknya dengan risiko membingungkan ( $a$ likelihood of confusion) atau dengan kata lain, ada satu persamaan yang membingungkan (a likelihood of confusion). ${ }^{7}$ Terminologi "persamaan pada pokoknya" dapat dilihat pada penjelasan Pasal 21 ayat (1) UU Merek sebagai berikut:

\footnotetext{
${ }^{3}$ Tim Lindsey, (ed.), Hak Kekayaan Intelektual Suatu Pengantar, P.T. Alumni, Bandung, 2013, hlm. 5

${ }^{4}$ Rahmi Jened, Hukum merek (Trademark Law) Dalam Era Global dan Integrasi Ekonomi, Prenadamedia Group, Jakarta, 2015, hlm. 4

${ }^{5}$ Uche U. Ewelukwa, "Comparative Trademark Law: Fair Use Defense in The United States and EuropeThe Changin Landscape of Trademark Law”, Widener Law Review, volume 13, 2006, hlm. 101

${ }^{6}$ Julie C. Frymark, "Trademark Dilution: A Proposal to Stop the Infection from Spreading", Valparaiso University Law Review, Volume 38, 2003, hlm. 170

${ }^{7}$ Rahmi Jened, Hukum Merek, Op. Cit., hlm. 181
} 
"Yang dimaksud dengan "persamaan pada pokoknya" adalah kemiripan yang disebabkan oleh adanya unsur yang dominan antara merek yang satu dengan merek yang lain sehingga menimbulkan kesan adanya persamaan, baik mengenai bentuk, cara penempatan, cara penulisan atau kombinasi antara unsur, maupun persamaan bunyi ucapan, yang terdapat dalam merek tersebut."

Berdasarkan penjelasan di atas dapat ditarik sebuah kesimpulan bahwa persamaan pada pokoknya bertitik tolak pada kebingungan konsumen. Apabila konsumen melihat suatu merek yang memiliki kemiripan dan konsumen tersebut terkecoh (karena terdapat persamaan) sehingga membeli produk dengan merek yang tidak ia kehendaki. Hal tersebut terjadi karena konsumen mengira produk dengan merek yang memiliki persamaan tersebut berasal dari sumber yang sama.

Seiring berkembangnya perdagangan barang dan/atau jasa, maka pelanggaran terhadap merek pun mengalami perkembangan. Perkembangan tersebut berupa pelanggaran yang merupakan suatu persaingan usaha curang, dimana suatu pihak menikmati jerih payah orang lain sehingga mendapatkan keuntungan secara instan. Pelanggaran tersebut bukan hanya berdasarkan pada persamaan pada keseluruhan dan/atau persamaan pada pokoknya namun berdasarkan pada hilangnya keunikan sebuah merek.

Keunikan sebuah merek dapat hilang apabila digunakan oleh pihak lain tanpa seizin pemilik merek. Schecter berpendapat bahwa untuk menjaga keunikan sebuah merek, maka segala penggunaan merek yang sama dengan merek tersebut haruslah dilarang walaupun penggunaan merek tersebut digunakan pada barang dan/atau jasa yang tidak saling berkompetisi. Hal ini dikarenakan sebagian merek khususnya merek terkenal, mempunyai nilai jual (selling power) yang dapat mempengaruhi konsumen untuk membeli suatu produk. Perlindungan terhadap keunikan sebuah merek seharusnya menjadi rasio dasar perlindungan merek. ${ }^{8}$ Pemikiran Schecter akhirnya berbuah pada sebuah teori perlindungan yang berfokus pada perlindungan merek sebagai properti bukan perlindungan merek sebagai perlindungan konsumen (mencegah kebingungan konsumen). Perlindungan ini dikenal dengan istilah dilusi merek. ${ }^{9}$

\footnotetext{
${ }^{8}$ Teks aslinya berbunyi the preservation of the uniqueness of a trademark should constitute the only rational basis for its protection dalam Frank I. Schecter, Op. Cit., hlm. 831

9 Paul Edward Kim, "Preventing Dilution of The Federal Trademark Dilution Act: Why The FTDA Requires Actual Economic Harm", University of Pennyslvania Law Review, Volume 150, No. 2, 2011, hlm. $722-725$
} 
Dilusi merek belum mendapatkan pengaturan secara eksplisit di dalam UU Merek, namun di dalam masyarakat terjadi beberapa kasus unik yang memerlukan suatu pendekatan baru yang tidak hanya mendasarkan suatu pelanggaran merek berdasarkan persamaan pada keseluruhan dan/atau persamaan pada pokoknya.

Dilusi merek secara sederhana dapat dikatakan terjadi ketika suatu merek mempunyai persamaan namun tidak saling berkompetisi satu dengan yang lain sehingga tidak menimbulkan kebingungan terhadap konsumen. Salah satu contoh kasus di Indonesia yang menarik untuk dibahas adalah kasus IKEA vs IKEMA karena terdapat kemiripan di antara kedua merek tersebut tetapi kedua merek tersebut tidak berada dalam satu kelas barang dan jasa.

Tulisan ini juga akan meninjau kasus serupa yang terjadi di Thailand. Alasan memilih Thailand sebagai perbandingan dikarenakan sistem hukum di Thailand sama dengan sistem hukum di Indonesia yaitu sistem hukum eropa kontinental. Kasus yang terjadi di Thailand adalah kasus STARBUCKS vs STARBUNG. Di antara kedua merek tersebut terdapat kemiripan, namun kemiripan tersebut tidak mengakibatkan kebingungan bagi konsumen karena perbedaan kelas konsumen antara konsumen STARBUCKS dengan STARBUNG.

\section{Rumusan Masalah}

Berdasarkan uraian di atas maka masalah yang hendak dibahas dalam artikel ini adalah: Pertama, apakah kasus IKEA v IKEMA yang terjadi di Indonesia dan kasus STARBUCKS v STARBUNG di Thailand termasuk ke dalam dilusi merek? Kedua, bagaimana perlindungan hukum terhadap merek terkenal dari dilusi merek di Indonesia dan Thailand?

\section{Tujuan Penelitian}

Tujuan penelitian ini yaitu pertama, untuk mengetahui kasus IKEA v IKEMA yang terjadi di Indonesia dan kasus STARBUCKS v STARBUNG di Thailand termasuk ke dalam dilusi merek. Kedua, untuk mengetahui perlindungan terhadap merek terkenal dari dilusi merek di Indonesia dan Thailand. 


\section{Metode Penelitian}

Metode penelitian yang digunakan adalah yuridis normatif dengan pendekatan undang-undang (statute approach), pendekatan kasus (case approach), pendekatan analitis (analytical approach) dan pendekatan perbandingan (comparative approach). Sumber data yang dipakai dalam penelitian ini menggunakan data sekunder. Adapun yang dimaksud dengan data sekunder terdiri dari : 1) Bahan Hukum primer, yaitu bahan-bahan hukum yang mengikat seperti: UndangUndang Nomor 20 Tahun 2016 tentang Merek dan Indikasi Geografis, UndangUndang Anti Dilusi Amerika Serikat dan Undang-Undang Merek Thailand, 2) Bahan hukum sekunder yaitu bahan-bahan hukum yang memberikan penjelasan mengenai bahan hukum primer, seperti doktrin, karya-karya ilmiah para sarjana, jurnal dan tulisan-tulisan lain yang bersifat ilmiah. Penelitian terhadap bahan hukum sekunder ini dimaksudkan untuk membantu menganalisis dan memahami bahan hukum primer. 3) Bahan hukum tersier, yaitu bahan-bahan hukum yang memberikan petunjuk maupun penjelasan terhadap bahan hukum primer dan bahan hukum sekunder, contohnya kamus umum, kamus istilah hukum, ensiklopedia, data internet yang berkaitan dengan penelitian. ${ }^{10}$ Analisis data dilakukan secara deskriptif kualitatif. Spesifikasi penelitian ini menggunakan deskriptif analitis, yaitu memaparkan data sebagaimana adanya untuk kemudian dilakukan analisis terhadap data tersebut berdasarkan kaidah-kaidah yang relevan. Deskriptif analitis digunakan untuk memberi data seteliti mungkin tentang suatu keadaan atau gejala yang ada dan dimaksudkan untuk membantu dan memperkuat teori-teori yang berhubungan.

\section{Hasil Penelitian dan Pembahasan}

\section{Kasus di Indonesia dan Thailand yang Termasuk ke dalam Dilusi Merek}

Dilusi merek pada awalnya berasal dari konsep yang dicetuskan oleh Franc I Schecter melalui artikel yang dimuat dalam jurnal Harvard Law Review. ${ }^{11}$ Dalam artikelnya yang berjudul The Rational Basis of Trademark Protection ia berkesimpulan

10 Soerjono Soekanto dan Sri Mamudji, Penelitian Hukum Normatif; Suatu Tinjauan Singkat, Raja Grafindo Persada, Jakarta, 2011, hlm. 13

${ }^{11}$ Dalam Robert G Bone, "Schecter's Ideas In Historical Context and Dilution Rocky Road”, Santa Clara High Technology Law Journal Volume 24, Issue 3, 2008, hlm. 470 
bahwa menjaga keunikan sebuah merek seharusnya menjadi satu-satunya rasio dasar perlindungan merek. Ia menarik kesimpulan tersebut dari kasus sengketa merek yang terjadi di Jerman yaitu kasus merek terkenal "Odol". ${ }^{12}$ Dalam kasus tersebut merek Odol yang merupakan merek pasta gigi digunakan dan didaftarkan oleh pihak lain sebagai merek besi. Pengadilan Jerman memutuskan bahwa penggunaan merek Odol walaupun pada barang atau jasa yang tidak saling berkompetisi merupakan "gegen die guten sitten" yang berarti berlawanan dengan moral yang baik. ${ }^{13}$

Schecter berpendapat bahwa untuk menjaga keunikan sebuah merek, maka segala penggunaan merek yang sama dengan merek tersebut haruslah dilarang walaupun penggunaan merek tersebut digunakan pada barang dan atau jasa yang tidak saling berkompetisi. Hal ini dikarenakan bagi sebagian merek khususnya merek terkenal, mempunyai nilai jual (selling power) yang dapat mempengaruhi konsumen untuk membeli suatu produk. Nilai jual dapat mengalami kemerosotan bahkan hilang sama sekali apabila terdapat banyak pihak yang menggunakan merek yang sama dengan merek yang mempunyai nilai jual (selling power) walaupun penggunaan demikian tidak menyebabkan kebingungan pada konsumen karena kedua merek pada barang dan atau jasa tidak saling berkompetisi. Schecter memberikan contoh merek Odol yang apabila digunakan oleh banyak pihak pada barang dan atau jasa yang tidak sejenis walaupun tidak menyebabkan kebingungan pada konsumen, akan menyebabkan keunikan pada merek Odol menjadi hilang, Odol yang tadinya dikenal hanya sebagai merek pasta gigi, berubah menjadi merek yang digunakan pada banyak barang dan atau jasa, sehingga merek Odol tidak lagi ekslusif lagi sebagai merek pasta gigi. ${ }^{14}$

Revisi Undang-Undang Anti Dilusi Amerika Serikat 2006 (Trademark Dilution Revision Act of 2006 selanjutnya disebut TDRA) menyatakan bahwa tindakan dilusi

12 Dalam Walter J. Derenberg, “The Problem of Trademark Dilution and the Antidilution Statutes", California Law Review Volume 44, Issue 3, 1956, hlm. 448

13 Barton Beebe, "The Suppressed Misappropriation Origins of Trademark Antidilution Law: the Landgericht Elberfeld's Odol Opinion and Frank Schecter's The Rational Basis of Trademark Protection", NYU School of Law, Public Law Research Paper No. 13-36, 2013, hlm. 2.

14 Barton Beebe, "Search and Persuasion in Trademark Law", Michigan Law Review, Volume 103, Issue 8, 2005, hlm. 2044-2046. 
merek dibagi menjadi dua bentuk yaitu blurring (pengaburan) dan tarnishment (pencemaran).

Berkaitan dengan konsep dilusi dan juga pelanggaran merek, konsep persaingan curang juga perlu dibahas. Berdasarkan Black's Law Dictionary, persaingan curang adalah: ${ }^{15}$

"Persaingan yang tidak wajar atau persaingan yang curang dalam perdagangan dan komersial, terutama praktik-praktik yang mencoba untuk menjual dengan menipu barang-barang atau jasa-jasa miliknya dengan mengimitasi atau memalsukan nama, merek, atau karakteristik pembeda milik kompetitor lain; suatu wadah hukum untuk melindungi pemakai pertama terhadap kompetitor yang mengimitasi atau memalsukan."

Dilusi merek berkaitan dengan persaingan usaha curang yang dibahas di dalam Pasal 6 bis Konvensi Paris:

“Negara-negara anggota Persatuan setuju secara ex officio dan sepanjang tidak bertentangan dengan perundang-undangan negaranya, atau berdasarkan permohonan dari seorang pihak yang berkepentingan, untuk menolak atau membatalkan suatu pendaftaran merek dan melarang penggunaan dari suatu merek dagang yang merupakan hasil penggandaan, pemalsuan, atau terjemahan hingga menimbulkan kebingungan atas suatu merek yang dianggap oleh pihak yang berwenang dari negara pendaftar, atau menolak untuk menggunakan merek yang cukup terkenal di negara itu dari seorang yang berhak atas manfaat patennya berdasarkan Konvensi ini dan menggunakannya terhadap barang dagangan yang identik atau yang hampir sama dengannya. Ketentuan-ketentuan ini juga berlaku apabila bagian penting (utama) dari merek tersebut merupakan hasil gandaan dari merek terkenal atau hasil pemalsuan yang dapat menimbulkan kebingungan."

Tidak ada kewajiban yang diatur dalam Konvensi Paris untuk melindungi merek dari dilusi. Walaupun perlindungan yang diberikan terhadap merek terkenal sudah diatur dalam Article 6 bis Konvensi Paris, pengaturan tersebut masih berbasiskan kebingungan yang merupakan konsep tradisional pelanggaran merek. Lebih jauh lagi, penggunaan merek hanya dibatasi sepanjang mengandung persamaan pada keseluruhan atau pada pokoknya yang bertolak secara kontras dengan konsep teoritis dari dilusi yaitu penggunaan merek pada barang yang tidak

${ }^{15}$ Unfair competition is dishonest or fraudulent rivaly in trade and commerce, especially the practice of trying to palm off one's own goods or services for those of another by imitating or counterfeiting a competitor's name, brand, or, distinctive characteristic; the body of law protecting the first user against an imitating or counterfeiting competitor. Henry Campbell Black, Black's Law Dictionary Centennial Sixth Edition, St. Paul, Minn: West Publishing co., 1990. 
sejenis. ${ }^{16}$ Sehingga Konvensi Paris hanya memberikan perlindungan terhadap merek terkenal dari perbuatan hasil penggandaan, pemalsuan, atau terjemahan hingga menimbulkan kebingungan atas suatu merek yang dianggap oleh pihak yang berwenang dari negara pendaftar.

Pasal 10 bis ayat (2) Konvensi Paris merumuskan bahwa persaingan curang adalah setiap perbuatan mengenai persaingan yang bertentangan dengan praktikpraktik wajar (honest practices) dalam industri dan perdagangan. ${ }^{17}$ Berdasarkan ketentuan Konvensi Paris, yang termasuk ke dalam ruang lingkup persaingan curang: 18

1. Semua perbuatan, yang dengan cara apapun, dapat menciptakan kekeliruan berkenaan dengan asal-usul suatu barang atau berkenaan dengan usahausaha industri atau perdagangan dari pihak pengusaha yang sedang bersaing;

2. Pemberitahuan yang palsu sehingga dapat mendiskreditkan perusahaan, barang atau aktivitas industri dan dagang dari pihak pengusaha yang bersaing;

3. Semua indikasi dan perbuatan yang dapat mengacaukan publik berkenaan dengan sifat barang, proses pembuatannya, ciri-ciri serta cara penggunaannya maupun tujuan atau kuantitas dari barang bersangkutan.

Dapat dikatakan bahwa dilusi berbeda dengan persaingan curang. Apabila dilihat dari titik tolaknya, dilusi bertitik tolak pada fungsi merek sebagai sarana pemasaran, sedangkan persaingan curang bertitik tolak pada fungsi merek sebagai sarana informasi mengenai asal-usul produsen suatu produk. Selain itu, pada dilusi tidak dibutuhkan pembuktian mengenai kebingungan pada konsumen, sedangkan pada konsep persaingan curang, pembuktian mengenai kebingungan pada konsumen merupakan hal yang mutlak.

\footnotetext{
${ }^{16}$ Sathita Wimonkunarak, "The Introduction of Trademark Dilution: The Review of Dilution Concept in ASEAN”, Thailand Law Journal 2014 Spring Issue 1, Volume 17, 2014, hlm. 1.

${ }^{17}$ Any act of competition contrary to honest practices in industrial or commercial matters constitutes an act of unfair competition.

18 The following in particular shall be probibited: 1. all acts of such a nature as to create confusion by any means whatever with the establishment, the goods, or the industrial or commercial activities, of a competitor; 2. false allegations in the course of trade of such a nature as to discredit the establishment, the goods, or the industrial or commercial activities, of a competitor; 3. indications or allegations the use of which in the course of trade is liable to mislead the public as to the nature, the manufacturing process, the characteristics, the suitability for their purpose, or the quantity, of the goods. Terjemahan diambil dari Achmad Zen Purba, Hak Kekayaan Intelektual Pasca TRIPs, Alumni, Bandung, 2005, 38.
} 
Amerika Serikat telah mengatur secara khusus dan tegas mengenai dilusi merek. Sedangkan di Eropa, tidak dikenal istilah dilusi, namun terdapat istilah yang seperti yaitu "causing detriment to the distinctive character" yang diatur dalam ketentuan pada Pasal 4 ayat (4) huruf (a) Trademark Directive. Pengaturan mengenai Dilusi di Eropa juga digabung dengan pengaturan mengenai persaingan curang. Syarat suatu merek mendapat perlindungan dari dilusi adalah bahwa merek tersebut adalah merek terkenal.

Merek terkenal mengandung makna "terkenal" menurut pengetahuan umum masyarakat. Merek terkenal yaitu merek yang dikenal luas oleh sektor-sektor relevan di dalam masyarakat. Promosi merupakan sarana paling efektif untuk membangun reputasi (image). Reputasi tidak harus diperoleh melalui pendaftaran, melainkan dapat diperoleh melalui actual use in placing goods or service into the market (penggunaan secara aktual dengan cara meletakkan barang dan jasa di pasar). ${ }^{19}$

World Intellectual Property Organization (WIPO) saat ini sedang memprakarsai persetujuan baru di bidang merek yang dirancang bagi perlindungan merek terkenal yang di dalamnya terdapat norma baru:20

a. Upaya memperjelas pengertian "relevant sector of the public" dengan unsur penentu.

b. Hanya sebatas pada konsumen potensial

c. Jaringan distribusi dan lingkungan bisnis yang biasa dengan merek terkenal pada umumnya.

d. Upaya penentuan elemen merek terkenal meliputi:

1. Jangka waktu, lingkup dan wilayah penggunaan merek.

2. Pasar.

3. Tingkat daya pembeda.

4. Kualitas harus baik (image).

5. Luas sebaran pendaftaran di dunia, sifat ekslusifitas pendaftaran yang dimiliki.

6. Luas sebaran penggunaan di dunia.

7. Sifat eksklusifitas penggunaan di dunia.

8. Nilai perdagangan merek tersebut di dunia.

9. Rekor perlindungan yang berhasil diraih.

10. Hasil litigasi dalam penentuan terkenal atau tidaknya merek tersebut.

11. Intensitas pendaftaran merek lain yang mirip dengan merek yang bersangkutan.

${ }^{19}$ Rahmi Jened, Hukum Merek..., Op. Cit., hlm. 242

20 Tetsuo Katsube, Protection of Wellknown/Famous Trademark, dalam Rahmi Jened, Hukum Merek, Op. Cit., hlm. 242-243 
Tidak ada definisi merek terkenal dalam UU Merek Indonesia, namun dalam penjelasan Pasal 21 ayat (1) Huruf b terdapat kriteria merek terkenal:

"Penolakan Permohonan yang mempunyai persamaan pada pokoknya atau keseluruhan dengan merek terkenal milik pihak lain untuk barang dan/atau jasa yang sejenis dilakukan dengan memperhatikan pengetahuan umum masyarakat mengenai merek tersebut di bidang usaha yang bersangkutan. Di samping itu, diperhatikan pula reputasi merek tersebut yang diperoleh karena promosi yang gencar dan besar-besaran, investasi di beberapa negara di dunia yang dilakukan oleh pemiliknya, dan disertai bukti pendaftaran merek dimaksud di beberapa negara. Jika hal tersebut belum dianggap cukup, Pengadilan Niaga dapat memerintahkan lembaga yang bersifat mandiri untuk melakukan survei guna memperoleh kesimpulan mengenai terkenal atau tidaknya merek yang menjadi dasar penolakan."

Di Amerika Serikat, hanya merek terkenal yang memiliki daya pembeda dan dikenal secara nasional yang memperoleh perlindungan dari dilusi. Sedangkan merek terkenal yang dilindungi dalam Pasal 6 bis Konvensi Paris namun mereknya tidak digunakan di Amerika, tidak mendapat perlindungan dari dilusi. Di Eropa, misalnya di Jerman, kriteria tertentu mengenai merek terkenal tidak diperlukan. Hal seperti, pangsa pasar, angka penjualan suatu produk barang/jasa, dan lain sebagainya dapat menjadi pertimbangan dalam menentukan kriteria merek terkenal.

Dilusi merek secara sederhana dapat dikatakan terjadi ketika suatu merek mempunyai persamaan namun tidak saling berkompetisi satu dengan yang lain sehingga tidak menimbulkan kebingungan terhadap konsumen. Salah satu contoh kasus di Indonesia yang menarik untuk dibahas adalah kasus IKEA vs IKEMA.

Pada 2011, IKEA melalui Inter IKEA Systems BV menggugat PT. Angsa Daya (Tergugat I) dan Departemen Hukum dan HAM RI (Tergugat II), di Pengadilan Niaga Jakarta Pusat, perkara No. 39/Merek/2011/ PN.Niaga.Jkt.Pst, tanggal 8 April 2011. Dalam perkara ini, merek IKEA yang diaku sebagai coined mark atau merek karena bukan berasal dari nama/kata-kata umum, mendalilkan sebagai merek terkenal di dunia sejak tahun 1943, yang di Indonesia terdaftar dalam barang kelas 21, kelas 24, kelas 11, kelas 35 dan kelas 42, sedangkan Angsa Daya sebagai pemilik merek IKEMA dengan produk barang kelas 19 digugat karena telah meniru, menjiplak dan membonceng keterkenalan merek IKEA. Sebabnya, merek 
IKEMA memiliki persamaan pada keseluruhan atau pada sebagian dengan IKEA, sehingga dapat menyesatkan atau mengecoh konsumen. IKEA juga mendalilkan kelas barang merek IKEMA memiliki persamaan jenis atau kelas barang dengan merek IKEA, atas dasar persamaan asal (herkost), cara pembuatan, sifat (aard) dan tujuan dari pemakaian barang.

Angsa Daya menganggap produk IKEMA yang terdaftar dalam kelas 19 (tegel, keramik lantai dan dinding), berbeda dengan produk IKEA yang termasuk kelas 21, kelas 24, kelas 11, kelas 35 dan kelas 42, sehingga tidak melanggar Pasal 6 ayat (1) Undang-Undang Nomor 15 Tahun 2001 tentang Merek. ${ }^{21}$ Selain itu, dijelaskan pula bahwa nama IKEMA tidak memiliki kemiripan bunyi, tulisan dan lafal dengan IKEA. Argumentasi Angsa Daya lain adalah padanan diantara beberapa merek, bahkan untuk kelas barang yang sama, tetap dinyatakan tidak melanggar hukum seperti NIKE dengan UNIKER, IKEAS, CIKEAS dan ILEKEA, demikian juga antara COLA COLA milik the Coca Cola Company (kelas 30) dengan KOLA KOLA milik PT. Forisa Nusapersada (kelas 30)

Putusan tingkat pertama, ${ }^{22}$ merek IKEA dinyatakan sebagai merek terkenal, ${ }^{23}$ terhadap tuntutan "persamaan merek", majelis hakim juga menyimpulkan kesamaan merek antara IKEA dengan IKEMA, sehingga pembatalan merek IKEMA dikabulkan. Putusan ini kemudian pada tingkat kasasi dikuatkan. ${ }^{24}$ Namun, pada tingkat peninjauan kembali 25 (perkara No. 165 PK/Pdt.Sus/2012), majelis PK menyatakan:

a. merek IKEA tidak memiliki persamaan pada pokoknya dengan IKEMA sebagaimana argumentasi Angsa Daya mengenai asal-usul dan lafal IKEMA yang berasal dari bahasa Tiongkok;

b. merek IKEMA yang terdaftar dalam kelas 19 bukan merupakan barang sejenis atau sekelas dengan merek IKEA yang terdaftar dalam kelas 11, 21, 24, 35, 42;

c. penerapan Pasal 6 ayat (2) mengenai "merek terkenal" terkait dengan Peraturan Pemerintah yang memerlukan persyaratan, dan hingga saat ini belum ada. ${ }^{26}$

${ }^{21}$ Undang-Undang ini sudah diganti dengan Undang-Undang Nomor 20 tahun 2016 tentang Merek dan Indikasi Geografis.

22 Putusan Nomor 39/Merek/2011/PN. Niaga.Jkt.Pst. tentang sengketa merek IKEA v IKEMA. IKEMA.

${ }^{23}$ Halaman 67 Putusan Nomor 39/Merek/2011/PN. Niaga.Jkt.Pst. perihal sengketa merek IKEA v

${ }^{24}$ Putusan Nomor 697 K/Pdt.Sus/2011 tentang sengketa merek IKEA v IKEMA.

${ }_{25}$ Putusan Nomor 165 PK/Pdt.Sus/2012 tentang sengketa merek IKEA v IKEMA.

26 "HaKI: Membaca Aneka Sengketa merek IKEA", http://wyndra-associate.com/new/2016/ 10/12/haki-aneka-sengketa-merek-ikea/, diakses tanggal 10 Februari 2018. 
Contoh Kasus yang terjadi di Thailand adalah kasus STARBUCKS vs STARBUNG. STARBUCKS mempermasalahkan penggunaan logo STARBUNG yang menyerupai logo STARBUCKS. Dalam kasus ini, hukum merek Thailand belum mengenal konsep dilusi merek, sehingga pihak STARBUCKS tidak dapat menggunakan dilusi merek sebagai dasar gugatan. Terdapat kelemahan bagi pihak STARBUCKS apabila menggugat berdasarkan confusion (kebingungan) yang merupakan dasar dalam menentukan telah terjadinya pelanggaran merek atau tidak. Dalam kasus tersebut merek STARBUNG digunakan oleh pedagang kaki lima sehingga sulit dipercaya bahwa telah terjadi kebingungan di dalam masyarakat. Adapun faktor-faktor yang melatarbelakangi adalah perbedaan harga, ukuran dan konsep kedai kopi yang berbeda antara STARBUCKS dengan STARBUNG. Faktorfaktor tersebut tidak dapat disangkal merupakan faktor-faktor yang signifikan yang membuat STARBUCKS dan STARBUNG berbeda di mata publik.

Kasus IKEA vs IKEMA dan STARBUCKS vs STARBUNG, mempunyai persamaan yaitu ketiadaan kebingungan konsumen. Ketiadaan kebingungan konsumen pada kasus IKEA vs IKEMA terjadi karena kelas barang yang berbeda. Sedangkan dalam STARBUCKS vs STARBUNG terdapat kemiripan, namun kemiripan tersebut tidak mengakibatkan kebingungan bagi konsumen karena perbedaan kelas konsumen antara konsumen STARBUCKS dengan STARBUNG.

Berdasarkan dua kasus tersebut di atas dapat disimpulkan bahwa dua kasus tersebut merupakan kasus dilusi merek dimana terdapat suatu pihak yang mencoba mengurangi keunikan sebuah merek terkenal pihak lain dengan menggunakan tanpa izin seluruh atau sebagian unsur merek terkenal tanpa izin walaupun penggunaan tersebut tidak mengakibatkan kebingungan bagi konsumen.

\section{Perlindungan Terhadap Merek Terkenal dari Dilusi Merek di Indonesia dan Thailand}

Hukum merek tradisional bertujuan untuk meningkatkan kualitas perdagangan barang dan atau jasa dengan melarang pemakaian tanda-tanda perdagangan yang menipu konsumen. Tanda-tanda yang membingungkan konsumen mengurangi efisiensi pasar dengan mengakibatkan konsumen membeli produk yang salah. Lebih luasnya, perlindungan terhadap integritas suatu tanda 
memungkinkan konsumen untuk menghabiskan lebih sedikit waktu dan usaha dalam mencari produk yang diinginkan dan dengan begitu mereduksi biaya pencarian. ${ }^{27}$

Baik Indonesia maupun Thailand belum mengatur secara eksplisit mengenai dilusi merek. Namun dapat kita temukan pengaturan yang mengatur mengenai perlindungan merek terkenal yang berbeda kelas barang dan/atau jasa. Dalam Pasal 21 ayat (1) UU Merek menyatakan bahwa:

"Permohonan ditolak jika Merek tersebut mempunyai persamaan pada pokoknya atau keseluruhannya dengan:

a. Merek terdaftar milik pihak lain atau dimohonkan lebih dahulu oleh pihak lain untuk barang dan/atau jasa sejenis;

b. Merek terkenal milik pihak lain untuk barang dan/atau jasa sejenis;

c. Merek terkenal milik pihak lain untuk barang dan/atau jasa tidak sejenis yang memenuhi persyaratan tertentu; atau

d. Indikasi Geografis terdaftar."

Selain alasan-alasan tersebut pada Pasal 21 ayat (1) UU Merek terdapat alasan lain yaitu diatur dalam Pasal 21 ayat (3) UU Merek berbunyi: "Permohonan ditolak jika diajukan oleh Pemohon yang beriktikad tidak baik." Dalam Pasal 21 ayat (1) huruf c diatur bahwa permohonan ditolak jika merek tersebut mempunyai persamaan pada pokoknya atau keseluruhannya dengan merek terkenal milik pihak lain untuk barang dan/atau jasa tidak sejenis yang memenuhi persyaratan tertentu. Sayangnya dalam penjelasan UU Merek tidak ditemukan penjelasan lebih lanjut mengenai "persyaratan tertentu" yang diatur dalam Pasal tersebut. Lebih lanjut lagi dalam Pasal 21 ayat (4) UU Merek diatur bahwa:

"Ketentuan lebih lanjut mengenai penolakan Permohonan Merek sebagaimana dimaksud pada ayat (1) huruf a sampai dengan huruf $c$ diatur dengan Peraturan Menteri."

Ketentuan lebih lanjut dapat ditemukan dalam Peraturan Menteri Hukum dan Hak Asasi Manusia Republik Indonesia Nomor 67 Tahun 2016 tentang Pendaftaran Merek (selanjutnya disebut Permen Merek) tepatnya dalam Pasal 17 ayat (2) mengenai kriteria penentuan barang dan/atau jasa sejenis yang selengkapnya berbunyi:

${ }^{27}$ Laura R. Bradford, "Emotion, Dilution, and the Trademark Consumer", Berkeley Technology Law Journal, Volume 23, Issue 4 Fall, 2008, hlm. 1231. 
"Kriteria penentuan barang dan/atau jasa sejenis sebagaimana dimaksud dalam Pasal 16 ayat (2) huruf a dan huruf b dapat berupa barang dengan barang, barang dengan jasa, atau jasa dengan jasa dengan ditentukan berdasarkan:
a. sifat dari barang dan/atau jasa;
b. tujuan dan metode penggunaan barang;
c. Komplementaritas barang dan/atau jasa;
d. kompetisi barang dan/atau jasa;
e. saluran distribusi barang dan/atau jasa;
f. konsumen yang relevan; atau
g. asal produksi barang dan/atau jasa."

Permen Merek tersebut juga menjabarkan lebih spesifik mengenai penilaian persamaan pada pokoknya yang diatur dalam Pasal 17 ayat (1) Permen Merek yang berbunyi:

"Penilaian persamaan pada pokoknya sebagaimana dimaksud dalam Pasal 16 ayat (2) dilakukan dengan memperhatikan kemiripan yang disebabkan oleh adanya unsur yang dominan antara Merek yang satu dengan Merek yang lain sehingga menimbulkan kesan adanya persamaan, baik mengenai bentuk, cara penempatan, cara penulisan atau kombinasi antara unsur, maupun persamaan bunyi ucapan, yang terdapat dalam Merek tersebut."

Kriteria Merek terkenal memiliki pengaturan yang lebih spesifik dalam Pasal 18 Permen Merek yang berbunyi:

(1) Kriteria penentuan Merek terkenal sebagaimana dimaksud dalam Pasal 16 ayat (2) huruf b dan huruf $\mathrm{c}$ dilakukan dengan memperhatikan pengetahuan umum masyarakat mengenai merek tersebut di bidang usaha yang bersangkutan.

(2) Masyarakat sebagaimana dimaksud pada ayat (1) merupakan masyarakat konsumen atau masyarakat pada umumnya yang memiliki hubungan baik pada tingkat produksi, promosi, distribusi, maupun penjualan terhadap barang dan/atau jasa yang dilindungi oleh Merek terkenal dimaksud.

(3) Dalam menentukan kriteria Merek sebagai Merek terkenal sebagaimana dimaksud pada ayat (1) dilakukan dengan mempertimbangkan:

a. tingkat pengetahuan atau pengakuan masyarakat terhadap Merek tersebut di bidang usaha yang bersangkutan sebagai Merek terkenal;

b. volume penjualan barang dan/atau jasa dan keuntungan yang diperoleh dari penggunaan merek tersebut oleh pemiliknya;

c. pangsa pasar yang dikuasai oleh Merek tersebut dalam hubungannya dengan peredaran barang dan/atau jasa di masyarakat;

d. jangkauan daerah penggunaan Merek;

e. jangka waktu penggunaan Merek;

f. intensitas dan promosi Merek, termasuk nilai investasi yang dipergunakan untuk promosi tersebut; 
g. pendaftaran Merek atau permohonan pendaftaran Merek di negara lain;

h. tingkat keberhasilan penegakan hukum di bidang Merek, khususnya mengenai pengakuan Merek tersebut sebagai Merek terkenal oleh lembaga yang berwenang; atau

i. nilai yang melekat pada Merek yang diperoleh karena reputasi dan jaminan kualitas barang dan/atau jasa yang dilindungi oleh Merek tersebut."

Permen Merek tersebut juga mengatur lebih lanjut mengenai merek terkenal yang diatur dalam Pasal 19 Permen Merek yang berbunyi:

(1) Permohonan ditolak jika mempunyai persamaan pada pokoknya atau keseluruhannya dengan merek terkenal milik pihak lain sebagaimana dimaksud dalam Pasal 16 ayat (2) huruf b dan huruf c dilakukan dengan mempertimbangkan kriteria sebagaimana dimaksud dalam Pasal 18.

(2) Penolakan Permohonan dilakukan berdasarkan Merek terkenal untuk barang dan/atau jasa yang tidak sejenis sebagaimana dimaksud dalam Pasal 16 ayat (2) huruf c harus memenuhi persyaratan tertentu.

(3) Persyaratan tertentu sebagaimana dimaksud pada ayat (2) meliputi: a. adanya keberatan yang diajukan secara tertulis oleh pemilik Merek terkenal terhadap Permohonan; dan b. Merek terkenal yang sudah terdaftar.

(4) Keberatan sebagaimana dimaksud pada ayat (3) huruf a harus memuat alasan dan disertai bukti yang cukup bahwa Permohonan oleh pihak lain tersebut mempunyai persamaan pada pokoknya atau keseluruhannya untuk barang dan/atau jasa yang tidak sejenis dengan Merek milik pemohon keberatan yang dimohonkan oleh pihak lain merupakan Merek terkenal.

Uraian pasal-pasal tersebut di atas menunjukkan bahwa suatu merek akan ditolak apabila mempunyai persamaan pada pokoknya merek terkenal milik pihak lain untuk barang dan/atau jasa tidak sejenis yang memenuhi persyaratan tertentu sebagaimana diatur dalam Pasal 17 ayat (2) Permen Merek dan merek terkenal tersebut harus memenuhi kriteria dalam Pasal 18 Permen Merek, dan yang paling utama harus disertai bukti yang cukup bahwa Permohonan oleh pihak lain tersebut mempunyai persamaan pada pokoknya atau keseluruhannya untuk barang dan/atau jasa yang tidak sejenis dengan Merek milik pemohon keberatan yang dimohonkan oleh pihak lain merupakan merek terkenal.

Faktor yang menjadi penentu terjadinya pelanggaran merek masih bersumber pada ada atau tidaknya persamaan pada pokoknya atau keseluruhannya antara satu merek dengan merek yang lainnya. Penentuan kemiripan ini sangatlah subyektif dan sangat bergantung pada pertimbangan hakim. Dapat diambil contoh 
kasus IKEA vs IKEMA yang menurut pandangan hakim tidak terdapat persamaan pada pokoknya antara merek IKEA vs IKEMA.

Berdasarkan uraian pasal-pasal di atas dapat ditarik kesimpulan bahwa Indonesia belum mengatur mengenai dilusi merek. Walaupun sudah mengatur mengenai penolakan permohonan merek yang mempunyai persamaan pada keseluruhan dan/atau persamaan pada pokoknya dengan merek terkenal pihak lain yang berbeda jenis barang dan/atau jasa tetapi hal tersebut masih mendasarkan pada persamaan pada keseluruhan dan/atau persamaan pada pokoknya, bukan pada keunikan sebuah merek terkenal yang merupakan esensi yang hendak dilindungi dari tindakan dilusi merek oleh pihak lain.

Perlindungan merek di Thailand diatur dalam Thai Trade Mark Act 1991 (selanjutnya disebut TMA). Terdapat beberapa ketentuan yang menyerupai pengaturan merek di Indonesia. Salah satunya dalam Section 13 TMA:

"the Registrar shall not register a trademark applied for upon finding that: (1) it is the same as a trademark that is already registered by someone else or; (2) it is so similar to another's registered trademark that the public might be confused or misled as to the proprietor or origin of the goods, provided the application is for goods of the same class or for goods of a different class found by the Registrar to be of the same character.'"

Bahwa ketentuan dalam Section 13 TMA mensyaratkan kemiripan yang menyebabkan masyarakat mungkin bingung atau menyesatkan mengenai sumber suatu barang baik dalam kelas yang sama maupun yang berbeda. Apabila hanya dilihat dari ketentuan bahwa kemiripan pada kelas barang yang sama maupun yang berbeda saja, dapat ditafsirkan bahwa Thailand mengatur mengenai dilusi merek. Namun, dilusi merek tidak hanya sebatas perbedaan barang dan/atau jasa, esensi dari dilusi merek adalah hilangnya keunikan sebuah merek terkenal akibat penggunaan oleh pihak lain tanpa memperhitungkan akibat adanya kebingungan dari masyarakat. ${ }^{28}$

Aturan lainnya terdapat dalam Section 8 (9) TMA yang berfungsi sebagai syarat absolut untuk menolak pendaftaran merek, yang berbunyi: "Trademarks that have or consist of any of the following characteristics shall not be registrable: (9) any mark which is contrary to public order, morality or public policy." Aturan ini digunakan untuk menolak pendaftaran merek yang melanggar ketertiban umum dan seringkali

${ }^{28}$ Sathita Wimonkunarak, Op. Cit., hlm. 3 
digunakan untuk menolak pendaftaran merek yang terbukti milik pihak lain, walaupun merek tersebut tidak terdaftar di Thailand. Sebagai contoh: CHANEL SA berhasil membatalkan pendaftaran LIFEFORD CHIC CHANEL yang berada di kelas yang sama, walaupun terdapat perbedaan di antara merek tersebut dan tidak adanya kebingungan publik. Trademark Board Thailand mempertimbangkan bahwa kata "CHANEL" dipilih dengan iktikad buruk dan bertentangan dengan ketertiban umum. Sayangnya, penerapan ketentuan ini sangat tergantung pada diskresi dari pejabat yang berwenang, sehingga terdapat kemungkinan terhadap situasi yang sama mendapatkan hasil yang berbeda. ${ }^{29}$

Aturan dalam Section 8 (10) TMA yang berbunyi: "Trademarks that have or consist of any of the following characteristics shall not be registrable:- (10) a mark registered or not, which is identical with a well-known mark as prescribed by the Ministerial Notifications, or so similar thereto that the public might be confused as to the owner or origin of the goods;" mengatur mengenai perlindungan merek terkenal, diberikan tanpa mengharuskan suatu merek terdaftar atau tidak di Thailand, terhadap merek yang identik atau sangat mirip, yang dapat mengakibatkan kebingungan publik terhadap asal suatu produk barang dan atau jasa. Dalam aturan ini, kebingungan juga merupakan faktor yang disyaratkan.

Berdasarkan aturan-aturan mengenai hukum merek di Thailand tersebut, maka dapat dilihat bahwa perlindungan merek di Thailand masih terbatas dan mendasarkan pada kebingungan konsumen. Kerugian yang disebabkan oleh dilusi terkadang tidak dapat dibuktikan dengan penerapan aturan-aturan merek yang mendasarkan pada kebingungan. Sehingga, sejatinya Indonesia dan Thailand belum mengatur mengenai dilusi merek. Keduanya hanya mengatur mengenai perlindungan merek terkenal dari penggunaan pihak lain secara tanpa izin yang mempunyai persamaan secara keseluruhan atau persamaan pada pokoknya dalam kelas barang dan/atau jasa yang berbeda.

\section{Penutup}

Berdasarkan uraian pembahasan di atas, maka dapat disimpulkan pertama, kasus IKEA vs IKEMA di Indonesia dan kasus STARBUCKS vs STARBUNG 
merupakan kasus dilusi merek dimana tidak terdapat kebingungan konsumen namun penggunaan seluruh maupun sebagian unsur dari suatu merek terkenal tanpa izin dapat mengurangi keunikan sebuah merek terkenal.

Kedua, baik Indonesia maupun Thailand belum mengatur secara spesifik mengenai dilusi merek. Indonesia hanya mendasarkan perlindungan pada persamaan pada keseluruhan dan/atau persamaan pada pokoknya sementara Thailand hanya mendasarkan perlindungan pada confusion (kebingungan). Ketiadaan persamaan pada keseluruhan maupun persamaan pada pokoknya akan mengakibatkan suatu merek terkenal di Indonesia tidak dapat membatalkan atau mengajukan suatu gugatan terhadap pihak yang memanfaatkan dan/atau menggunakan seluruh maupun sebagian unsur dari mereknya.

\section{Daftar Pustaka}

\section{Buku}

Black, Henry Campbell, Black's Law Dictionary Centennial Sixth Edition, St. Paul, Minn, West Publishing co., 1990.

Jened, Rahmi, Hukum merek (Trademark Law) Dalam Era Global dan Integrasi Ekonomi, Prenadamedia Group, Jakarta, 2015.

Lindsey, Tim (ed.), Hak Kekayaan Intelektual Suatu Pengantar, P.T. Alumni, Bandung, 2013.

Purba, Achmad Zen, Hak Kekayaan Intelektual Pasca TRIPs, Alumni, Bandung, 2005.

Soekanto, Soerjono dan Sri Mamudji, Penelitian Hukum Normatif; Suatu Tinjauan Singkat, Raja Grafindo Persada, Jakarta, 2011.

\section{Jurnal}

Beebe, Barton, "Search and Persuasion in Trademark Law", Michigan Law Review, Volume 103, Issue 8, 2005.

, "The Suppressed Misappropriation Origins of Trademark Antidilution Law: the Landgericht Elberfeld's Odol Opinion and Frank Schecter's The Rational Basis of Trademark Protection," NYU School of Law, Public Law Research Paper No. 13-36, 2013.

Bone, Robert G., "Schecter's Ideas In Historical Context and Dilution Rocky Road", Santa Clara High Technology Law Journal Volume 24, Issue 3, 2008.

Bradford, Laura R., "Emotion, Dilution, and the Trademark Consumer", Berkeley Technology Law Journal, Volume 23, Issue 4 Fall, 2008.

Derenberg, Walter J., "The Problem of Trademark Dilution and the Antidilution Statutes", California Law Review Volume 44, Issue 3, 1956. 
Ewelukwa, Uche U., "Comparative Trademark Law: Fair Use Defense in The United States and Europe-The Changin Landscape of Trademark Law", Widener Law Review, volume 13, 2006.

Frymark, Julie C., "Trademark Dilution: A Proposal to Stop the Infection from Spreading", Valparaiso University Law Review, Volume 38, 2003.

Kim, Paul Edward, "Preventing Dilution of The Federal Trademark Dilution Act: Why The FTDA Requires Actual Economic Harm", University of Pennyslvania Law Review, Volume 150, No. 2, 2011.

Rafianti, Laina dan Amirulloh, M., "Perlindungan merek Terkenal Di Indonesia Berdasarkan Ketentuan Hukum Internasional Dibandingkan Dengan Trademark Dilution Revision Act Of 2006 Amerika Serikat", Laporan Penelitian Fakultas Hukum Universitas Padjadjaran, Bandung, 2008.

Schecter, Frank I., "The Rational Basis of Trademark Protection”, Harvard Law Review, Volume 40, No. 6, April 1927.

Wimonkunarak, Sathita, "The Introduction of Trademark Dilution: The Review of Dilution Concept in ASEAN", Thailand Law Journal 2014 Spring Issue 1, Volume 17, 2014.

\section{Peraturan Perundang-Undangan}

Undang-Undang Nomor 15 Tahun 2001 Tentang Merek, Lembaran Negara Republik Indonesia Tahun 2001 Nomor 110, Tambahan Lembaran Negara RI Nomor 4131.

Undang-Undang Nomor 20 Tahun 2016 Tentang Merek Dan Indikasi Geografis, Lembaran Negara Republik Indonesia Tahun 2016 Nomor 252, Tambahan Lembaran Negara RI Tahun 2016 Nomor 252.

Peraturan Menteri Hukum dan Hak Asasi Manusia Republik Indonesia Nomor 67 Tahun 2016 Tentang Pendaftaran Merek, Berita Negara Republik Indonesia Tahun 2016 Nomor 2134.

\section{Internet}

"HaKI: Membaca Aneka Sengketa merek IKEA", http://wyndra associate.com/new/2016/10/12/haki-aneka-sengketa-merek-ikea/, diakses tanggal 10 Februari 2018.

\section{Putusan Pengadilan}

Putusan Pengadilan Niaga Nomor 39/Merek/2011/PN. Niaga.Jkt.Pst. tentang sengketa merek IKEA v IKEMA.

Putusan Kasasi Mahkamah Agung Nomor 697 K/Pdt.Sus/2011 tentang sengketa merek IKEA v IKEMA.

Putusan Peninjauan Kembali Mahkamah AgungNomor 165 PK/Pdt.Sus/2012 tentang sengketa merek IKEA v IKEMA. 